\title{
Multiple paternity in wild common shrews (Sorex araneus) is confirmed by DNA- fingerprinting
}

\author{
HÅKAN TEGELSTRÖM*, JEREMY SEARLE*, JOHN BROOKFIELD† \& SIMON MERCER* \\ Department of Genetics, Uppsala University, Uppsala, Sweden, *Department of Zoology, University of Oxford, South \\ Parks Road, Oxford, England and †Department of Genetics, University of Nottingham, Queens Medical Centre, \\ Nottingham, England
}

\begin{abstract}
We have tested for the occurrence of multiple paternity in wild common shrews by karyotypic analysis and DNA-fingerprinting of five wild-caught females and their litters. Karyotypic data suggest that some litters were sired by more than one male, but provide no definitive evidence. By using DNA-fingerprinting, it was possible to establish that two males sired the litter of two females. The present report shows that multiple paternity is not a rare phenomenon in the common shrew and by using DNA-fingerprinting it is possible to assign individual offspring to different male parents even when none of the putative fathers are available for inspection.
\end{abstract}

Keywords: DNA-fingerprinting, karyotypic analysis, multiple paternity, Sorex araneus.

\section{Introduction}

Common shrews (Sorex araneus) are extremely difficult to observe in their natural surroundings and there is therefore no substantial information on their mating behaviour in the wild. Ecological studies indicate that male common shrews do not normally have breeding territories but tend to be nomadic; presumably searching out or making themselves available to as many females as possible (Shillito, 1963; Michielsen, 1966). Male shrews do not contribute to the maintenance of the female or her young. Observations on captive, sexually-mature females (Dehnel, 1952; Crowcroft, 1957) indicate that they are sexually receptive for a period of $2 \mathrm{~h}$ and at other times are hostile to the male. In the laboratory, the observation that a male will mount a female a large number of times (Dehnel, 1952) suggests the opportunity for copulation with different males and the possibility for more than one male to sire offspring within one litter.

Multiple paternity has been demonstrated in the common shrew by karyotypic analysis of individuals caught in a region where Robertsonian chromosomal polymorphism is present (Searle, 1990). From the karyotypes of wild caught pregnant females and their

Correspondence: H. Tegelström, Department of Genetics, Uppsala University, Box 7003, S-750 07 Uppsala, Sweden. offspring it could be shown that more than one male contributed to 4 out of 16 pregnancies analysed. Studies of a large number of female common shrews provide no evidence that embryos are retained from one pregnancy to the next (Brambell, 1935; Searle, 1984; Tarkowski, 1957) and thus, the karyotypic analysis indicates that different males must have sired offspring during the short period when females are receptive.

From the typing of mother and offspring with simple Mendelian markers, such as chromosomes and enzyme variants, multiple paternity is demonstrated when more than two 'alleles' are shown to be transmitted on the male side. However, due to a generally low level of detectable variability in chromosomes and enzymes, studies of such markers are likely to underestimate the level of multiple paternity. Using methods where the level of detectable genetic variation is higher would enable a more detailed assessment of paternity. Polymorphisms in tandem-repetitive DNA-sequences ('minisatellites'), resulting from allelic variation in the number of repeats, show an extremely high level of heterozygosity, often exceeding 60 per cent (Nakamura et al., 1987). DNA probes isolated from a subset of human minisatellites with a core sequence of 10-15 bases (Jeffreys, 1987) and a cluster of 15-base repeats from the wild type M13 phage (Vassart et al., 1987) 
establish complex, individual-specific fingerprints (Jeffreys et al., 1985). These DNA-probes reveal high levels of genetic variability in various animals (Burke \& Bruford, 1987; Jeffreys \& Morton, 1987; Jeffreys et al., 1987; Wetton et al., 1987; Georges et al., 1988; Weiss et al., 1988; Burke et al., 1989).

In this report we have applied genetic fingerprinting using two highly variable minisatellite DNA-probes and analysis of Robertsonian chromosomal variation, to assess multiple paternity in the common shrew.

\section{Methods}

\section{Animals}

Five pregnant females were collected live from grassland sites near Oxford, UK and subsequently maintained in isolation. Female 2087 was caught in East Hendred while the others were from Cothill (site details in Searle, 1986). Females were allowed to rear their young until weaning and then the female and complete litters were killed and karyotyped according to the method of Searle (1986). Animals were stored at $-20^{\circ} \mathrm{C}$ until isolation of DNA. Altogether 36 individuals were fingerprinted (female no. $2087+7$ young, $2097+10$ young, $2098+6$ young, $2102+4$ young and $2103+4$ young). One additional member of the litter of female 2103 was karyotyped but not fingerprinted. Female 2097 and her young were not subjected to chromosomal analysis.

\section{DNA extraction}

Five-hundred microlitres of SET-buffer $(0.15 \mathrm{M} \mathrm{NaCl}$, 0.05 м Tris, $1 \mathrm{~mm}$ EDTA, pH 8.0, autoclaved) were added to the samples (0.3-0.4 g of muscle tissue) and placed in a $+55^{\circ} \mathrm{C}$ waterbath. Then, $25 \mu \mathrm{l}$ of 25 per cent $(\mathrm{w} / \mathrm{v})$ SDS and $75 \mu \mathrm{l}$ of Proteinase K (15 units sample ${ }^{-1}$ ) were added. The tubes were shaken gently and left for $1-2 \mathrm{~h}$ at $+55^{\circ} \mathrm{C}$. DNA was purified by two extractions with phenol/chloroform and two with chloroform. DNA was precipitated with 99 per cent ethanol at $-20^{\circ} \mathrm{C}$ and pelleted at $12,000 \mathrm{~g}$, washed with 70 per cent ethanol and vacuum dried. The DNA was dissolved overnight in $400 \mu \mathrm{l}$ of TE-buffer $(10 \mathrm{~mm}$ Tris, $1 \mathrm{~mm}$ EDTA, pH 7.0, autoclaved). DNA (8-10 $\mu \mathrm{g}$ in $400 \mu \mathrm{l}$ ) was digested with 30 units of Hae III for $5 \mathrm{~h}$ at $37^{\circ} \mathrm{C}$, extracted once with phenol/chloroform, once with chloroform and then precipitated as above. The digested DNA was redissolved overnight in $25 \mu \mathrm{l}$ of TE. Electrophoresis of DNA-fragments was performed in 0.8 per cent agarose gels for $24-28 \mathrm{~h}$ at $1.7 \mathrm{~V} \mathrm{~cm}^{-1}$ and transferred to Biodyne nylon membranes by vacuum blotting.

\section{Hybridization}

The insert of human minisatellite clone 33.15 (Jeffreys et al., 1985) and a 2900 fragment from wild type M13 (Vassart et al., 1987) were isolated by preparative restriction enzyme digestion and electrophoresis in low melting-point agarose. The probe DNA was purified from the agarose using Gene Clean (Bio 101). Probe DNA (50-100 ng) was labelled within ${ }^{32} \mathrm{P}$ by the random primer method (Feinberg \& Vogelstein, 1983). Prehybridization and hybridization were performed according to Georges et al. (1988) using dried skimmed milk. Membranes were washed $2 \times 15 \mathrm{~min}$ in $2 \times$ SSC, 0.1 per cent SDS at room temperature, $2 \times 15$ $\min$ in $1.5 \times \mathrm{SSC}, 0.1$ per cent $\mathrm{SDS}$ at $+60^{\circ} \mathrm{C}$ and finally $2 \times 10 \mathrm{~min}$ in $1 \times \mathrm{SSC}$ at room temperature and exposed to $\mathrm{X}$-ray film (Kodak X-omat $\mathrm{AR}$ ) at $-70^{\circ} \mathrm{C}$ for 1-6 days with intensifying screens. Most membranes were subjected to different exposure times to visualize bands of different intensities. The DNA probe was removed by washing in $0.4 \mathrm{M} \mathrm{NaOH}$ and $0.2 \mathrm{~m}$ Tris, $\mathrm{pH} 7.5$, checked for remaining radioactivity and then used for rehybridization.

\section{Analysis}

Karyotypes of mother and offspring were analysed according to Searle (1990). The karyotypic and fingerprint analyses were performed independently and results were not compared until both were complete.

The DNA fingerprint analysis was based only on information from the mother and her offspring as we know nothing about the fingerprints of the possible fathers. The male bands could be inferred by comparing the presence of bands in the female with all her offspring. The average identity between female-offspring is about 65 per cent, which gives an estimated mean identity between unrelated individuals of 0.4 . The bandsharing of unrelated individuals is the probability that a band is present in a diploid zygote $(x=0.4)$ while $q$, the probability that a given band is present in a random gamete can be calculated from the Hardy-Weinberg formula $(q=1-\sqrt{1-x})$. We assume that $q$ is the same for all bands, in this case $q=0.225$.

Assuming that there is no mutation, no linkage, or allelism and that all bands have the same population frequency of $q$, it is possible to calculate the probabilities associated with the distribution of different combinations of paternal alleles between offspring (a data set) given alternative paternity hypotheses. The appropriate way to calculate the probability of obtaining the observed dataset is to compare two alternative hypotheses, that the offspring have a single father, and there are two fathers. These individual probabilities will both 
be very low, but the important statistic is their ratio, the likelihood ratio.

In the single father hypothesis, a paternal-specific band, found in some of the offspring but not others, must represent a heterozygous locus in that single father. The total probability of the data for that band is $2 q(1-q)(1 / 2)^{n}$. The first part of the equation is the Hardy-Weinberg probability that the father is a heterozygote for the band, and the second part is the probability of the precise distribution of the band seen in the $n$ offspring. The total probability of the dataset under this hypothesis is the product of the probabilities for all the paternal-specific bands. It is possible to calculate a corresponding probability for the hypothesis in which there are two fathers. It must be remembered, however, that there are $2^{n-1}-1$ different two-father hypothesis, which differ in the distribution of the two fathers across the offspring. It is illegitimate simply to take the most likely of these and compare it with the one-father hypothesis. Rather, the mean probability of obtaining the data across all these two-father hypotheses must be used. For more details of the methods used, see Brookfield (1989).

\section{Results and discussion}

\section{Karyotypic analysis}

The karyotypic data provide no definitive evidence for multiple paternity among the litters analysed. In fact, based on our knowledge of Robertsonian karyotypic variation in the Oxford area, this is not surprising. Among those pregnant females caught, only the single individual from East Hendred (2087) is from the interracial hybrid zone where certain chromosomes segregate for three 'alleles' (three different arrangements of the same chromosome arm: Searle, 1990). At Cothill, the other site sampled, all chromosomal polymorphisms are of the two 'allele' type.

In the litter of female 2103, equal numbers of heterozygous and homozygous offspring were expected for all three variable chromosomes if there was only a single sire. For one variable chromosome (no), four out of five offspring were heterozygous, for another $(p r)$ a different four offspring were homozygous, while for a third variable chromosome $(k q)$ segregation was as expected (three homozygotes: two heterozygotes). Thus, there is a slightly distorted segregation which may be the result of multiple paternity but the evidence is weak.

A more unusual segregation was observed in the litter of female 2087. Considering the only chromosome which varied among the litter (no), equal numbers of heterozygous and homozygous offspring were expected if there was only a single sire. In fact, six individuals were homozygous and only one individual (offspring 7) was heterozygous and showed a different karyotype from the other offspring. There was an additional peculiarity about the litter of female 2087 . One of the two 'alleles' of chromosome $p r$, the metacentric form of the chromosome, which is rather less common than the alternative twin-acrocentric form at East Hendred (Searle, 1986) where the female was caught, was transmitted on the male side to all offspring. However, all one can say from the distorted segregation is that there is likely to be multiple paternity and off-spring 7 is the most likely to have a different father.

There is no indication of multiple paternity in litter 2102 as the female was heterozygous for all variable chromosomes and only four offspring were karyotyped, which minimizes the likelihood of detecting multiple paternity. There was no indication of multiple paternity in litter 2098 from karyotypic data. Female 2097 and her offspring were not karyotyped.

\section{DNA fingerprint analysis}

The average number of bands identified by the two probes in females is 19.4 where probe 33.15 often gives a slightly higher number. Among offspring, the mean total number of bands per individual detected by the two probes is 21.1 but the variation in band number per individual is considerable (range 14-28, Table 1). Comparisons of the same nylon membrane for whether the two probes detect identical fragments were negative and we therefore consider information from probes M13 and 33.15 to be independent.

The number of male-specific bands reconstructed from all offspring is 10 and 15 in the litters of females 2098 and 2102 respectively (two probes), 7 and 8 for litter 2103 and 2097 (only probe 33.15) and as high as 29 (two probes) for the offspring of female 2087 (Table $1)$.

The total number of male bands identified divided by the average number of bands within a litter would be expected to be slightly less than 60 per cent $(1-x)$. The ratio seen is close to this for litters 2103, 2098, and 2102. The higher figure (71 per cent) for litter 2097 is probably explained by random band segregation and by the fact that we used only one probe. This litter may, however, have been sired by a father with an unusual fingerprint pattern. In litter 2087, the ratio between the total number of male-specific bands and the average number of bands is very high ( 123 per cent, Table 1). The high number of male-specific bands (29) is evidence that more than one male has been involved in siring this litter. 
Table 1 The number of offspring and male-specific bands identified by the two probes used for the investigation of multiple paternity in five wild-caught female common shrews \{Sorex araneus\}

\begin{tabular}{|c|c|c|c|c|c|c|c|c|c|c|c|c|}
\hline \multirow[b]{2}{*}{ Female } & \multirow{2}{*}{$\begin{array}{l}\text { Number of } \\
\text { offspring }\end{array}$} & \multicolumn{4}{|c|}{$\begin{array}{l}\text { Average number of bands in } \\
\text { offspring }\end{array}$} & \multirow[b]{2}{*}{ Total } & \multirow[b]{2}{*}{ Range } & \multicolumn{2}{|c|}{$\begin{array}{l}\text { Number of } \\
\text { male-specific } \\
\text { bands }\end{array}$} & \multicolumn{2}{|c|}{$\begin{array}{l}\text { Number of } \\
\text { male-specific } \\
\text { bands per } \\
\text { individual }\end{array}$} & \multirow{2}{*}{$\begin{array}{l}\text { Total number of male } \\
\text { bands/average number } \\
\text { of bands per offspring }\end{array}$} \\
\hline & & M13 & Range & 33.15 & Range & & & M13 & 33.15 & M13 & 33.15 & \\
\hline 2087 & 7 & 12.3 & $9-15$ & 11.2 & $7-14$ & 23.5 & $16-28$ & 14 & 15 & 5.5 & 6.0 & $29 / 23.5=1.23$ \\
\hline 2097 & 10 & 6.7 & $4-10$ & 11.3 & $9-12$ & 18.0 & $14-21$ & - & 8 & - & 5.4 & $8 / 11.3=0.71$ \\
\hline 2098 & 6 & 8.7 & $6-11$ & 9.0 & $7-10$ & 17.7 & $16-21$ & 6 & 4 & 2.2 & 1.3 & $10 / 17.7=0.56$ \\
\hline 2102 & 4 & 11.3 & $10-13$ & 14.0 & $12-17$ & 25.3 & $22-28$ & 11 & 4 & 4.3 & 1.8 & $15 / 25.3=0.59$ \\
\hline 2103 & 4 & - & - & 14.5 & $12-17$ & - & - & - & 7 & - & 4.0 & $7 / 14.5=0.48$ \\
\hline Average & 6.2 & 9.7 & & 12.0 & & 21.1 & & 10.3 & 7.4 & 4.0 & 3.7 & \\
\hline
\end{tabular}

\section{Distribution of male-specific bands}

DNA fingerprinting showed no indication of multiple paternity in the offspring of females 2098 and 2097. The offspring of female 2103 was probed only with 33.15 and seven male-specific bands were found. Two of these were found in all individuals, two bands were found in one individual only. There are seven twofather models to be compared to the one-father model. The dataset is more likely with a one-father model than with a two-father model and the indication of multiple paternity by the karyotypic data is not confirmed.

In the litter of female 2102 (Table 2), offspring number 1 shows five male-specific bands not shown by the litter mates having five different male-specific bands with probe M13. This would be expected if one male had sired one individual and another male the other three offspring. Probe 33.15 shows very few male-specific bands (4). There are seven two-father models (with a $3: 1$ or a $2: 2$ split among the offspring) and the mean of the seven likelihood ratios and one (representing the one-father model) is $6.5 \times 10^{4}$, which indicates that the distribution of male-specific bands between offspring is much more likely if there are two fathers. Given that there are two fathers, there was a 97.8 per cent chance that offspring 1 had a different father from offspring 2, 3 and 4 . This case of apparent multiple paternity was not indicated by the karyotypic data.

In the litter of female 2087 there were 29 malespecific bands (Table 3). Five were found in one individual only, seven bands were found randomly distributed between offspring and could have been present in both male $\mathrm{A}$ and $\mathrm{B}$ (as expected from the average band-sharing between individuals). Seventeen out of 29 male bands had a non-random distribution between offspring. Thus, four M13 and four 33.15 male-
Table 2 Distribution of male-specific bands identified by the two probes M13 and 33.15 in the litter of wild-caught female 2102 where multiple paternity is suggested

\begin{tabular}{|c|c|c|c|c|}
\hline \multirow{2}{*}{$\begin{array}{l}\text { Male-specific } \\
\text { band number }\end{array}$} & \multirow{2}{*}{$\begin{array}{l}\text { Male A } \\
1\end{array}$} & \multicolumn{3}{|c|}{ Male B } \\
\hline & & 2 & 3 & 4 \\
\hline \multicolumn{5}{|l|}{ Probe M13 } \\
\hline 1 & & & & $\mathrm{x}$ \\
\hline 2 & & & $x$ & \\
\hline 3 & & $\mathrm{x}$ & & $\mathrm{x}$ \\
\hline 4 & $x$ & & & $\mathrm{x}$ \\
\hline 5 & $\mathrm{x}$ & & & \\
\hline 6 & $x$ & & & \\
\hline 7 & $x$ & & & \\
\hline 8 & $x$ & & & \\
\hline 9 & & $\mathrm{x}$ & $\mathrm{x}$ & $x$ \\
\hline 10 & $\mathrm{x}$ & & & \\
\hline 11 & & $\mathrm{x}$ & $\mathrm{x}$ & $\mathrm{x}$ \\
\hline Number of male bands & 6 & 3 & 3 & 5 \\
\hline \multicolumn{5}{|l|}{ Probe 33.15} \\
\hline 1 & $\mathrm{x}$ & & & $x$ \\
\hline 2 & $x$ & & $\mathrm{x}$ & $\mathrm{x}$ \\
\hline 3 & $\mathrm{x}$ & & & \\
\hline 4 & & & & $\mathrm{x}$ \\
\hline Number of male bands & 3 & 0 & 1 & 3 \\
\hline
\end{tabular}

specific bands characterize offspring 1, 3, 4 and 7 while another nine male-specific bands characterize offspring 2, 5 and 6 , which suggests multiple paternity, with two fathers (A and B) siring four and three offspring, respectively. The arithmetic mean of the likelihood ratios for 63 possible models is $3.36 \times 10^{15}$ with virtually all the probability derived from a model where 
Table 3 Distribution of male-specific bands identified by the two probes M13 and 33.15 in the litter of wild-caught female 2087 where multiple paternity is suggested

\begin{tabular}{|c|c|c|c|c|c|c|c|}
\hline \multirow{2}{*}{$\begin{array}{l}\text { Male-specific } \\
\text { band number }\end{array}$} & \multicolumn{4}{|c|}{ Male A } & \multicolumn{3}{|c|}{ Male B } \\
\hline & 1 & 3 & 4 & 7 & 2 & 5 & 6 \\
\hline \multicolumn{8}{|l|}{ Probe M13 } \\
\hline $1-$ & & & $\mathrm{x}$ & & & & \\
\hline $2^{*}$ & & $\mathrm{x}$ & $\mathrm{x}$ & & $\mathrm{x}$ & $\mathrm{x}$ & \\
\hline $3 \mathrm{~A}$ & $\mathrm{x}$ & $\mathrm{x}$ & $\mathrm{x}$ & & & & \\
\hline $4 B$ & & & & & $\mathrm{x}$ & & $\mathrm{x}$ \\
\hline $5 B$ & & & & & $\mathrm{x}$ & $\mathrm{x}$ & $\mathrm{x}$ \\
\hline $6 \mathrm{~B}$ & & & & & $\mathrm{x}$ & $\mathrm{x}$ & $\mathrm{x}$ \\
\hline $7-$ & & & & $\mathrm{x}$ & & & \\
\hline $8 \mathrm{~A}$ & $\mathrm{x}$ & $\mathrm{x}$ & & $\mathrm{x}$ & & & \\
\hline 9- & & & & & & & $\mathrm{x}$ \\
\hline $10 \mathrm{~A}$ & $\mathrm{x}$ & $\mathrm{x}$ & $\mathrm{x}$ & & & & \\
\hline $11 \mathrm{~B}$ & & & & & $\mathrm{x}$ & $\mathrm{x}$ & $\mathrm{x}$ \\
\hline $12^{*}$ & $\mathrm{x}$ & & & & $\mathrm{x}$ & & \\
\hline $13 \mathrm{~A}$ & $\mathrm{x}$ & $\mathrm{x}$ & & & & & \\
\hline $14 B$ & & & & & $\mathrm{x}$ & & $\mathrm{x}$ \\
\hline Number of male bands & 5 & 5 & 4 & 2 & 7 & 4 & 6 \\
\hline \multicolumn{8}{|l|}{ Probe 33.15} \\
\hline $1 \mathrm{~A}$ & $\mathrm{x}$ & $\mathrm{x}$ & $\mathrm{x}$ & & & & \\
\hline $2 \mathrm{~B}$ & & & & & $\mathrm{x}$ & $\mathrm{x}$ & $\mathrm{x}$ \\
\hline $3 \mathrm{~B}$ & & & & & $\mathrm{x}$ & $\mathrm{x}$ & $\mathrm{x}$ \\
\hline $4 \mathrm{~A}$ & $\mathrm{x}$ & & $\mathrm{x}$ & $\mathrm{x}$ & & & \\
\hline $5^{*}$ & $\mathrm{x}$ & & & & $\mathrm{x}$ & & \\
\hline $6^{*}$ & $\mathrm{x}$ & & & & $\mathrm{x}$ & & \\
\hline $7 \mathrm{~A}$ & & $\mathrm{x}$ & $\mathrm{x}$ & & & & \\
\hline $8 \mathrm{~B}$ & & & & & & $\mathrm{x}$ & $\mathrm{x}$ \\
\hline $9 \mathrm{~A}$ & & $\mathrm{x}$ & $\mathrm{x}$ & & & & \\
\hline $10 \mathrm{~B}$ & & & & & & $\mathrm{x}$ & $x$ \\
\hline $11^{*}$ & $\mathrm{x}$ & $\mathrm{x}$ & & & & $\mathrm{x}$ & $\mathrm{x}$ \\
\hline $12-$ & & & & $x$ & & & \\
\hline $13-$ & $\mathrm{x}$ & & & & & & \\
\hline $14^{*}$ & & $\mathrm{x}$ & & & $\mathrm{x}$ & $\mathrm{x}$ & $\mathbf{x}$ \\
\hline $15^{*}$ & & $\mathrm{x}$ & $\mathrm{x}$ & & & & $\mathrm{x}$ \\
\hline Number of male bands & 6 & 6 & 5 & 2 & 5 & 5 & 7 \\
\hline
\end{tabular}

$\mathrm{A}$ and $\mathrm{B}=$ bands from putative males $\mathrm{A}$ and $\mathrm{B}$ respectively.

* = Bands present in both male A and B.

$-=$ Non-informative band.

offspring 1, 3, 4 and 7 have a different father from the others. The extremely high value of this likelihood ratio constitutes strong evidence that this litter was sired by two fathers. Given that there were two fathers, there is a 99.99 per cent chance that the distribution of offspring above between fathers is correct. The karyotypic data indicated that offspring 7 may have a different father compared to some or all of the other offspring. This was also confirmed by the DNA-fingerprint analysis.
We have not detected any cases of linkage as variable female bands showed Mendelian inheritance in the litters examined. An alternative explanation to multiple paternity for the association of bands in offspring would be linkage, which can be tested. If there was only one father for all offspring, and he was heterozygous for the loci studied, on average half of the offspring would have the band and the other half would not. For litter 2087, with seven offspring, we would expect that each band on average would be found in 3.5 offspring. If we find that the representation of the bands among offspring is lower than this, then this constitutes evidence for double paternity which is independent of the evidence given above, and which cannot be the result of genetic linkage. For female 2087 each of the 29 male bands are found in, on average, 2.41 of the offspring, which is considerably less than the 3.5 expected. For the two-father hypothesis with offspring 2, 5 and 6 showing 11 male bands, each of these are found in, on average, 1.55 offspring compared to the 1.5 expected. For offspring 1, 3, 4 and 7 the 19 male bands are found in, on average, 1.84 of the offspring, which is close to the 2.0 expected. Thus, linkage is an unlikely explanation for the band distribution in litter 2087. The data for litter 2102, treated in the same way, are less convincing and do not resolve the issue for this litter but indicate the right direction.

\section{Conclusion}

Thus, karyotypic data indicated, but did not provide, definitive evidence for multiple paternity in two litters and it was not possible to assign particular offspring to particular fathers. DNA-fingerprinting provided clear evidence for two fathers siring the offspring of two out of five females and offspring could be assigned to particular fathers. In his karyotypic study, Searle (1990) found that among the offspring from 16 wild-caught female common shrews, there were four litters for which it was possible to demonstrate multiple paternity. In chromosomal analysis, multiple paternity can be detected only when sires of a particular litter happen to contribute three different chromosomal arrangements of the same chromosome arm, which is a common situation only in contact zones between chromosomal races. Even if the common shrew has one of the most variable karyotypes of any mammal (Wójcik \& Searle, 1988), analysis of chromosomal variation is likely to underestimate the frequency of multiple paternity.

Despite the small numbers of individuals examined, the present study suggests that multiple paternity is not a rare phenomenon in the common shrew, that DNAfingerprinting has the potential to reveal multiple 

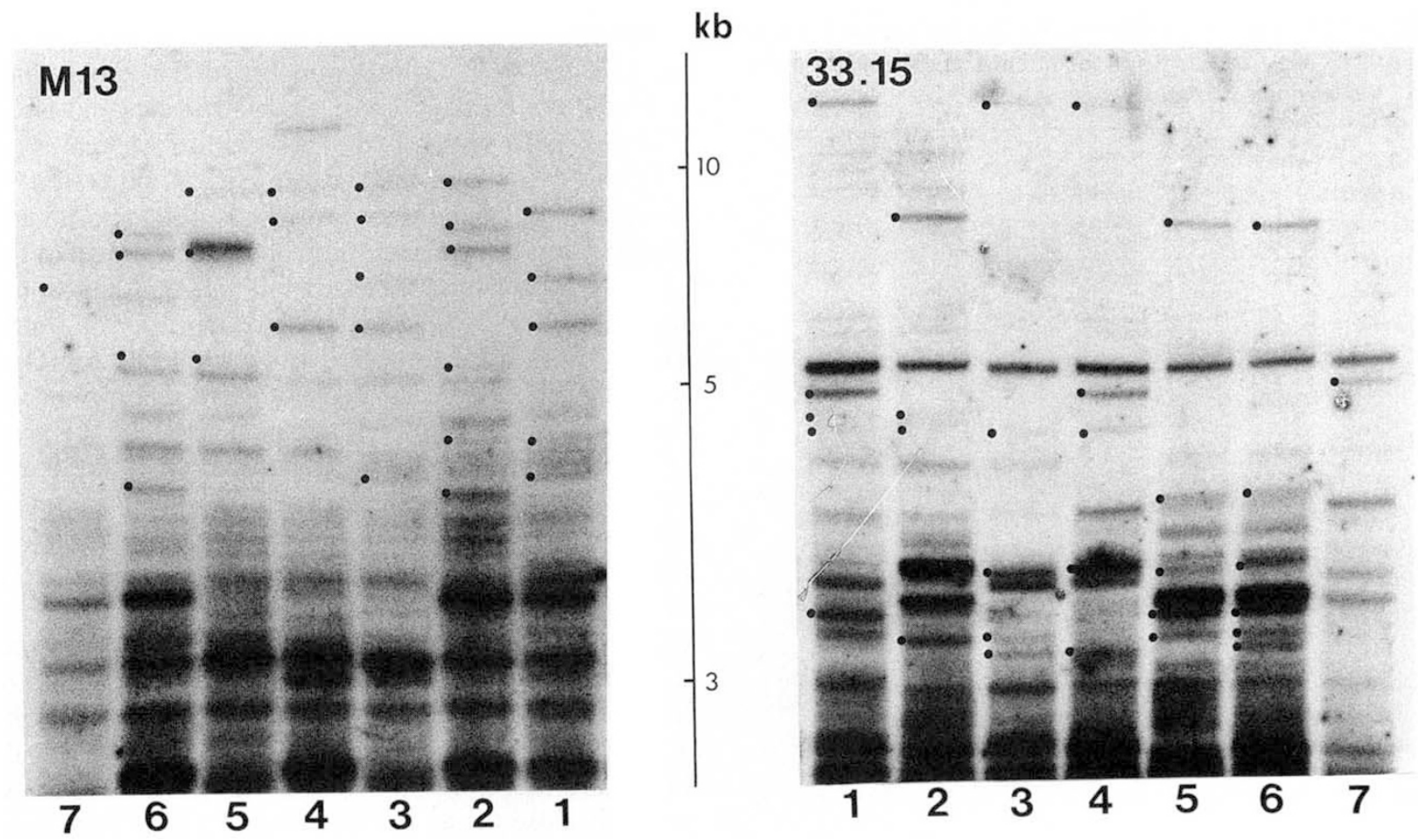

Fig. 1 DNA-fingerprints of the offspring $(1-7)$ of female 2087 where multiple paternity is suggested. Informative male-specific bands used in the analysis are indicated $(\bullet)$.

paternity and that it is possible to assign individual offspring to different male parents even when none of the putative fathers are available for inspection. In common with other species of mammal, where the male does not contribute to rearing the offspring (Ginsberg \& Huck, 1989), the mating system of the common shrew appears to be promiscuous. When multiple matings occur the promotion of sperm competition (Parker, 1970) may represent a female strategy and our understanding of such sperm manipulation is of great importance for the evaluation of mating strategies and social organization (Dewsbury \& Baumgardner, 1981; Birkhead \& Hunter, 1990).

\section{Acknowledgements}

We would like to thank Alec J. Jeffreys for the 33.15 minisatellite clone and Susanne Veenhuizen for technical assistance. The manuscript benefited from comments and suggestions from Cathy Jones, Kate Lessells, Honor Prentice and Paula Stockley. This investigation was supported by grants from the Swedish Natural Science Research Council (HT), the Erik Philip-Sörensen Foundation (HT), The Royal Society of London (JS) and the Natural Environment Research Council (SM).

\section{References}

BIRKHEAD, T. R. AND HUNTER, F. M. 1990. Mechanisms of sperm competition. Trends Ecol. Evol., 5, 48-52.

BRAMBELL, F. W. R. 1935. Reproduction in the common shrew (Sorex araneus Linnaeus). I. The oestrous cycle of the female. Phil. Trans. R. Soc. Lond., Series B, 225, 1-49.

BROOKFIELD, J. F. Y. 1989. How many fathers? Fingerprint News, 3, 7-9.

BURKE, T. AND BRUFORD, M. w. 1987. DNA fingerprinting in birds. Nature, 327, 149-152.

BURKE, T., DAVIES, N., BRUFORD, M. W. AND hATCHWELL, B. J. 1989. Parental care and mating behaviour of polyandrous dunnocks Prunella modularis related to paternity by DNA fingerprinting. Nature, 338, 249-251.

Crowcroft, P. 1957. The Life of the Shrew. Max Reinhardt, London.

DEHNEL, A. 1952. The biology of breeding of common shrew $S$. araneus L. in laboratory conditions. Annales Universitatis Mariae Curie-Slodowska, Series C, 6, 11, 359-376.

DEWSbury, D. A. AND Baumgardner, D. J. 1981. Studies of sperm competition in two species of muroid rodents. Behav. Ecol. Sociobiol., 9, 121-133.

FEINBERG, A. P. AND VOGELSTEIN, B. 1983. A technique for radiolabeling DNA restriction endonuclease fragments to high specific activity. Anal. Biochem., 132, 6-13.

GeORGES, M., Lequarre, A.-S., CASTElli, M., hANSET, R. AND 
VASSART, G. 1988. DNA fingerprinting in domestic animals using four different minisatellite probes. Cytogenet. Cell Genet., 47, 127-131.

GINSBERG, J. R. AND HUCK, U. W. 1989. Sperm competition in mammals. Trends Ecol. Evol., 4, 74-79.

JEFFREYS, A. J. 1987. Highly variable minisatellites and DNA fingerprints. Biochem. Soc. Trans., 15, 309-317.

JEFFREYS, A. J. AND MORTON, D. B. 1987. DNA fingerprints of dogs and cats. Anim. Genet., 18, 1-15.

JEFFREYS, A. J., WILSON, V. AND THEIN, S. L. 1985. Hypervariable 'minisatellite' regions in human DNA. Nature, 314, 67-73.

JEFFREYS, A. J., WILSON, V., KELLY, R., TAYLOR, B. A. AND BULFIELD, G. 1987. Mouse DNA 'fingerprints': analysis of chromosome localization and germline stability of hypervariable loci in recombinant inbred strains. Nuc. Acids Res., 15, 2823-2836.

MICHIELSEN, N. C. 1966. Intraspecific and interspecific competition in the shrews Sorex araneus L. and S. minutus L. Arch. Néerl. Zool., 17, 73-174.

NAKAMURA, Y., LEPPERT, M., o'CONNELL, P. et al. 1987. Variable number of tandem repeat (VNTR) markers for human gene mapping. Science, 235, 1616-1622.

PARKER, G. A. 1970. Sperm competition and its consequences in the insects. Biol. Rev., 45, 525-567.

SEARLE, J. B. 1984. Nondisjunction frequencies in Robertsonian heterozygotes from natural populations of the common shrew, Sorex araneus L. Cytogenet. Cell Genet.,
38, 265-271.

SEARLE, J. B. 1986. Factors responsible for a karyotypic polymorphism in the common shrew, Sorex araneus. Proc. $R$. Soc. Lond. B, 229, 277-298.

SEARLE, J. B. 1990 . Evidence for multiple paternity in the common shrew (Sorex araneus). J. Mammal., 71, 139-144.

SHILLITO (BABINGTON), J. F. 1963. Observations on the range and movements of a woodland population of the common shrew Sorex araneus L. Proc. Zool. Soc. Lond., 140, 533-546.

TARKOWSKI, A. K. 1957. Studies on reproduction and prenatal mortality of the common shrew (Sorex araneus L.) II. Reproduction under natural conditions. Annales Universitatis Mariae Curie-Sklodowska, Series C, 10, 177-244.

VASSART, G., GEORGES, M., MONSIEUR, R., BंROCAS, H., LEQUARRÉ, A.-S. AND CHRISTOPHE, D. 1987. A sequence in M13 phage detects hypervariable minisatellites in human and animal DNA. Science, 235, 683-684.

WEISS, M. L., WILSON, V., CHAN, C., TURNER, T. AND JEFFREYS, A. J. 1988. Application of DNA fingerprinting probes to Old world monkeys. Am. J. Primatol., 16, 73-79.

WETTON, J. H., CARTER, R. E., PARKIN, D. T. AND WALTERS, D. 1987. Demographic study of a wild house sparrow population by DNA fingerprinting. Nature, 327, 147-149.

WOJCIK, J. M. AND SEARLE, J. B. 1988. The chromosome complement of Sorex granarius - the ancestral karyotype of the common shrew (Sorex araneus)? Heredity, 61, 225-229. 